Clinical Case

\title{
A diaphragmatic tumor mimicking gastric neoplasm: a clinical case report
}

\author{
P.A. Burko' • M.G. Fedorova² • R.R. Iliasov³ • I.N. Mozhzhukhina ${ }^{4}$
}

Pavel A. Burko - MD, Radiologist, Department of Diagnostic Radiology'; ORCID: https://orcid.org/0000-0002-13449654

$\triangle 32$ Novyy Arbat ul., Moscow, 121099,

Russian Federation.

Tel.: +7 (977) 6241462 .

E-mail: pavelburko@gmail.com

Mariya G. Fedorova - MD, PhD, Associate Professor, Head of Chair of Morphology, Institute of Medicine ${ }^{2}$; ORCID: https:// orcid.org/0000-0003-4177-8460.

E-mail: fedorovamerry@gmail.com

Ruslan R. Iliasov - MD, Surgeon,

Department of Surgery ${ }^{3}$; ORCID: https:// orcid.org/0000-0003-0873-1804. E-mail:

diamonddoctor@mail.ru

Irina N. Mozhzhukhina - MD, PhD,

Associate Professor, Head of Chair of

Radiology4; ORCID: https://orcid.org/0000-

0002-0777-1604.

E-mail: mogira1972@yandex.ru
The vast majority of patients with tumors arising from the diaphragm do not have any specific clinical symptoms, therefore, computed tomography (CT) and magnetic resonance imaging (MRI) are the techniques required for the diagnosis. This is particularly relevant when a pathological mass has grown to an extent producing a "mass effect" on the adjacent organs. In some cases, clinical symptoms of arise due to the local invasion of the neoplasm to the adjacent tissues or distant metastases.

We present a rare clinical case of a mesenchymal diaphragmatic tumor in a 34-year-old patient. After a review of her clinical status and imaging of the abdomen, including CT and MRI, the preliminary diagnosis of the gastric neoplasm of uncertain behavior (D37.1) was made, despite the initial diagnostic assumption of the exogastric location of the mass based on MRI. After careful consideration of the diagnostic assessment results, a multidisciplinary decision was made to perform laparoscopic resection of the mass. The intraoperative finding was a tumor originating from the left diaphragmatic cupula with no involvement of the stomach. The patient's recovery was uneventful. Pathological examination revealed a solitary calcifying fibrous tumor of the diaphragm.

This clinical case shows that a mass arising from the diaphragm can mimic one arising from the gastric fundus, leading to an incorrect diagnosis and subsequent inappropriate management.

Key words: solitary fibrous tumor, mesenchymal tumor, diaphragm, stomach, computed tomography, magnetic resonance imaging

For citation: Burko PA, Fedorova MG, lliasov RR, Mozhzhukhina IN. A diaphragmatic tumor mimicking gastric neoplasm: a clinical case report. Almanac of Clinical Medicine. 2021;49(7):503-507. doi: 10.18786/2072-0505-2021-49-063.

Received 20 September 2021; revised 14 December 2021; accepted 17 December 2021; published online 20 December 2021

${ }^{1}$ National Medical Research Center of Rehabilitation and Balneology; 32 Novyy Arbat ul., Moscow, 121099, Russian Federation

${ }^{2}$ Penza State University; 40 Krasnaya ul., Penza, 440026, Russian Federation

${ }^{3}$ Clinic for Diagnostics and Management on Izmaylova; 71 Izmaylova ul., Penza, 440023, Russian Federation

${ }^{4}$ Penza Institute for Further Training of Physicians - Branch Campus of the Russian Medical Academy of Continuous Professional Education; 8A Stasova ul., Penza, 440060, Russian Federation

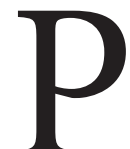
rimary tumors of the diaphragm are rare [1]. Solitary fibrous tumor of the diaphragm is a fairly rare benign neoplasm of mesenchymal origin. The etiology of these tumors has not been studied. In addition, prior publications have shown that the clinical presentation is nonspecific.
These tumors are usually surgically resected. In view of the rarity of the disease, there is no systematic data on it.

We present a rare case of a solitary calcifying fibrous tumor of the diaphragm, confirmed by radiological and pathological findings. This tumor 
mimicked a stomach wall neoplasm, which led to an underestimation of the required surgery volume and thus necessitated a prompt modification of the intraoperative procedure.

\section{Case report}

A 34-year-old female patient sought a consultation in the Clinic for Diagnostics and Management on Izmaylova (Penza, Russia) with a year-long history of recurrent heartburn and nausea.

Her physical examination was unremarkable, with normal vital signs (blood pressure $120 / 80 \mathrm{~mm} \mathrm{Hg}$, heart rate 80 beats/min, body temperature $36.7^{\circ} \mathrm{C}$, and respiratory rate 21 breaths $/ \mathrm{min}$ ) and no specific symptoms at abdominal examination.

The native and contrast-enhanced computed tomography (CT) of the abdomen performed in another clinic was available for a second-opinion radiology report. The native CT of the abdomen demonstrated a round heterogeneous partially calcified mass associated with the gastric fundus wall, of $12 \times 16 \mathrm{~mm}$ in diameter $(+145 \ldots+1010 \mathrm{HU})$ (Fig. 1). The exact location of the mass could not be determined due to the ectomorphic somatotype of the patient.

An abdominal contrast-enhanced CT (with iv and oral administration of the contrast) showed clear accumulation of the contrast agent in the arterial phase, as demonstrated by an increase in density by $32.7 \%$, compared to that in the non-contrast phase. This was followed by a $5 \%$ decrease in the venous phase and a subsequent increase by $13.2 \%$ in the delayed phase (Fig. 2). These changes indicated the adequate blood supply and presence of a fibrous stromal component. The initial hypothesis was that the neoplasm might arise from the stomach wall, although calcified stromal tumors of this location are rare. Significant calcification is an uncommon sign of gastrointestinal stromal tumors [2]. Further characterization of the abdominal mass with magnetic resonance imaging (MRI) showed a T2 hypointense, $\mathrm{T} 1$ isointense mass presumably arising from the gastric

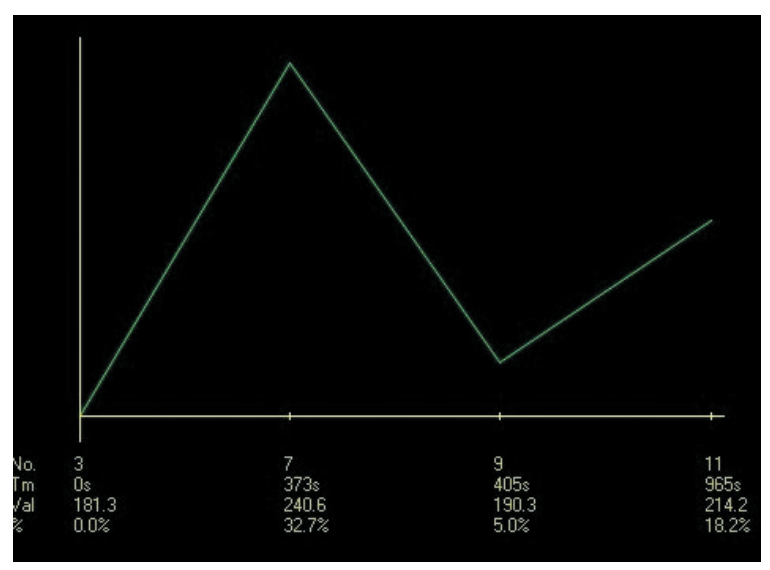

Fig. 2. The line of contrast enhancement (computed tomography)
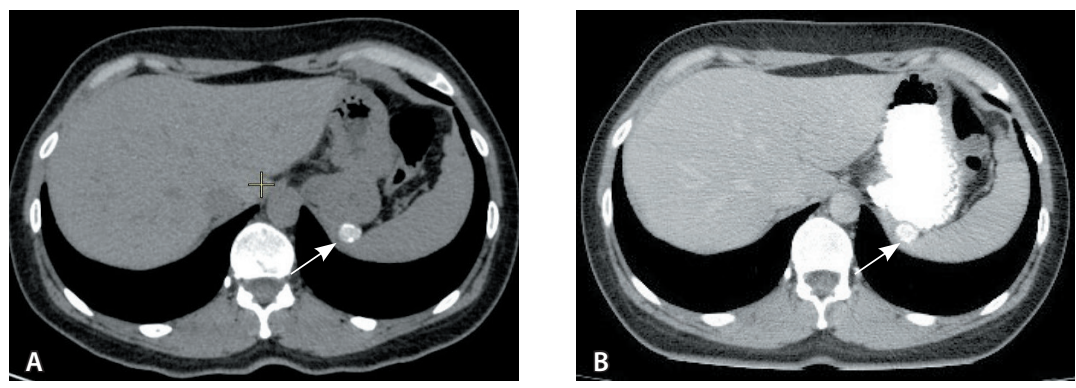

Fig. 1. Computed tomography of the abdomen showed a mass located in the region of the fundus of the stomach (arrows), the visceral surface of the spleen and the diaphragmatic dome: A, non-contrast; $\mathbf{B}$, intravenous contrast enhancement (portal venous phase) in conjunction with oral contrast

fundus. A contrast-enhanced scan revealed a hypovascular abdominal mass located outside from the gastric mucous membrane (Fig. 3).

The results of the workup have led to a theoretical assumption on the extra-gastric location of the mass, due to the presence of a T2-hyperintense dotted signal next to left semicircle of the mass behind the mucous membrane.

The decision was made to perform laparoscopic resection, with the preliminary diagnosis of gastric neoplasm of uncertain behavior (D37.1).

At the beginning of the procedure, intraoperative fibrogastroduodenoscopy was unable to visualize the mass in the posterior gastric wall area. After air insufflation and wall expansion, the mass was visualized along the posterior gastric wall near the fundus, corresponding to the diaphragmatic cupula. At laparoscopy, the gastric body was unremarkable and its wall unchanged. However, an oval, white mass of $200 \mathrm{~mm}$ in diameter, with even contours and dense consistency was found at the diaphragmatic cupula (Fig. 4). The neoplasm of the diaphragmatic cupula was successfully excised.

A gross specimen of the neoplasm of the left diaphragmatic cupula represented an oval, white, fibrous encapsulated mass with even contours, $20 \times 15 \mathrm{~mm}$ in size (Fig. 5).

Histologically, the specimen stained with hematoxylin eosin $(\times 100)$ showed calcifications, irregular connective tissue fibers and the tumor capsule. There were areas of fibrinoid swelling, akaryote areas of fibrinoid necrosis, and
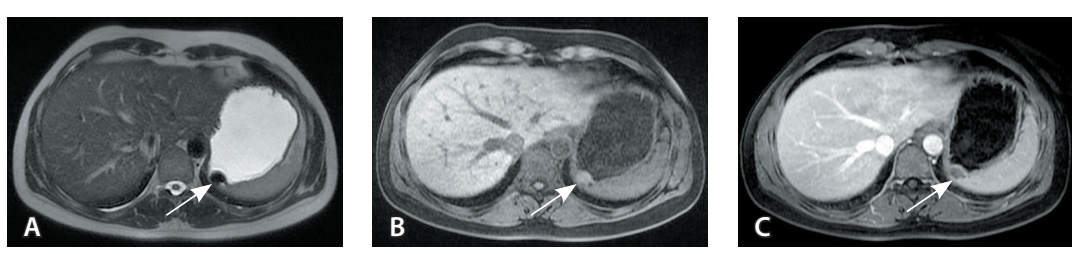

Fig. 3. Abdominal magnetic resonance imaging showed a mass located in the region of the fundus of the stomach, the visceral surface of the spleen and the diaphragmatic dome (arrows): A, T2-weighted image; B, T1-weighted image; C, T1-weighted 3D gradient echo LAVAflex sequence (post-gadolinium, $60 \mathrm{~s}$ ) 


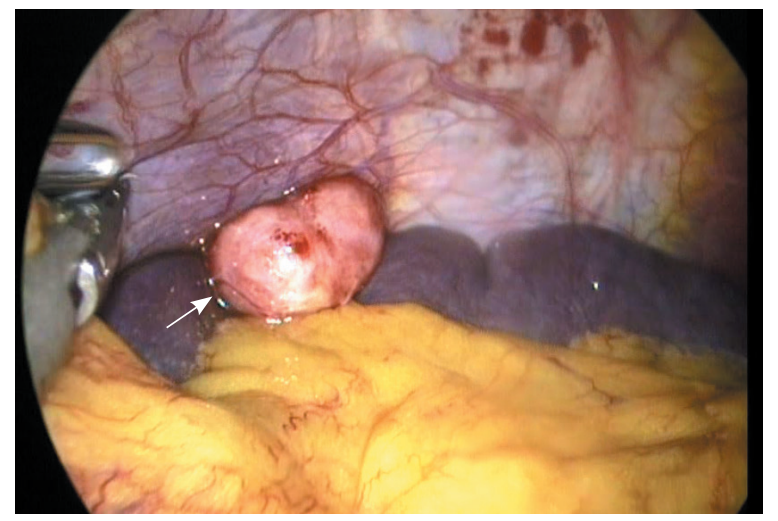

Fig. 4. Laparoscopic view of the tumor protruding into the abdominal cavity (arrow)

a small number of vessels with thin walls (Fig. 6). The pathomorphological diagnosis was a benign solitary calcifying fibrous tumor of mesenchymal origin.

The postoperative period was unremarkable. The patient was discharged for outpatient follow-up.

\section{Discussion}

Primary diaphragmatic tumors are rare, especially benign ones $[1,2]$. The diaphragm is usually involved secondary to pleural or peritoneal malignancies [3]. Solitary fibrous tumors are spindle-cell neoplasms that usually originate from the visceral or parietal pleura, as well as the peritoneum, and probably grow from either mesothelial cells or fibroblasts / primitive mesenchymal cells [4]. They are typically found in the thoracic cavity and sometimes the abdomen; however, other extra-thoracic and extra-abdominal locations have also been reported. In particular, neoplasms of the parotid salivary gland, ovary, orbit, bladder, and periosteum have been documented in the available literature [5].

Solitary fibrous tumors can occur at any age without any gender imbalance. They usually manifest after the fourth decade of life as a well-circumscribed, painless, slowly growing masses $[4,5]$.

M. Grancher was the first to describe a clinical case of a benign fibrous tumor of the diaphragm in 1868 [6]. Due to their extremely low prevalence, only 4 cases of solitary fibrous tumors occurring from the diaphragm have been reported in PubMed over the past two decades [7-10]. Moreover, all these cases were fibrous tumors originating from the diaphragmatic pleura. The last publication describing a clinical case of a solitary fibrous tumor emanating from the diaphragmatic peritoneum dates back to 2010 [10]. Unfortunately, there isn't enough data for statistical analysis, which hinders full understanding of the

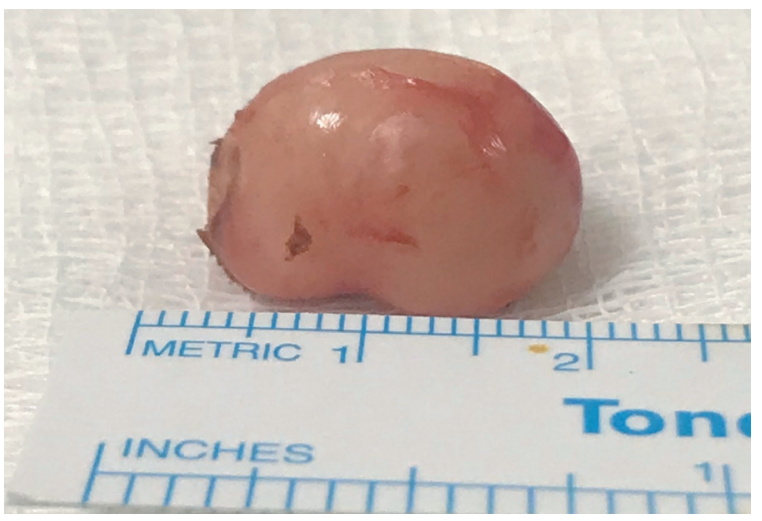

Fig. 5. Gross specimen. Solitary calcifying fibrous tumor of the diaphragm

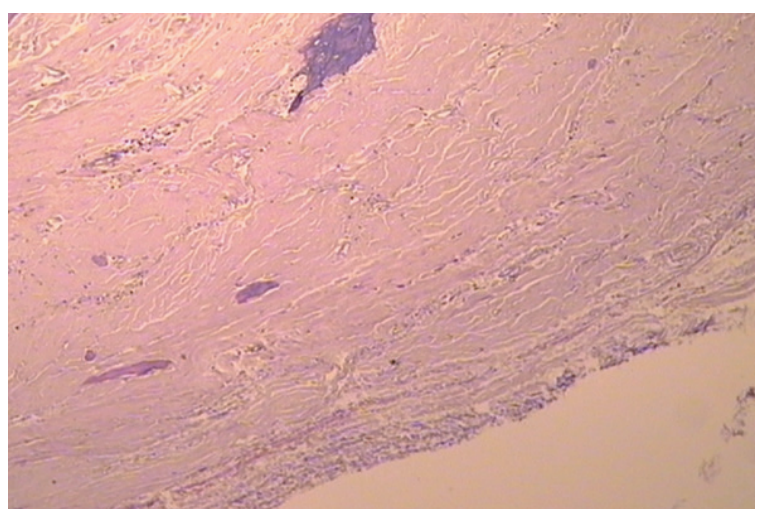

Fig. 6. Sectioned slide. Solitary calcifying fibrous tumor of the diaphragm (hematoxylin and eosin, $\times 100$ )

pathophysiological factors, clinical features, imaging characteristics, management, and analysis of the outcomes.

Surgical tumor resection is the management method of choice $[10,11]$, while there are no specific clinical or radiological signs that could distinguish malignant solitary fibrous tumors from benign ones [12]. It should also be borne in mind that a local recurrence is possible with incomplete excision and malignant transformation has been reported [5].

We present a rare case of a solitary calcifying fibrous tumor of the diaphragm confirmed by histopathological examination in a 34-year old patient.

The majority of patients with diaphragmatic tumors are asymptomatic, although symptoms may arise when the tumor has become large enough to exert a "mass effect" on the adjacent organs [8, 10, 13]. Clinical manifestations are usually related to the size of the tumor [9]. Our patient had a history of recurrent heartburn and nausea, which were probably unrelated to the underlying disease. The results of her physical examination were unremarkable. 
Medical imaging, such as CT and MRI, plays a key role in the diagnosis [14]. It is of note that MRI is comparable to CT, although MRI may have higher sensitivity for tissue differentiation around the mass helping to exactly map the location. For instance, even minimal peritoneal effusion may help determine the extra-gastric topography of a mass. Up-to-date imaging techniques are certainly indispensable in the diagnostic component of the disease management, but they cannot provide the final conclusion on the tumor type. Ultimately, a histological examination remains the gold standard for the clinical diagnosis.

The management of asymptomatic diaphragmatic fibrous tumors has not been algorithmized. Conservative management is preferred in the cases with a high risk of complications during any surgical procedure or when the patient clearly refuses surgery. Given that only pathological assessment a completely excised mass would establish a definitive diagnosis, the multidisciplinary team agreed that the patient would undergo surgery rather than a conservative approach and follow-up. The surgery for a fibrous diaphragmatic tumor is based on the classical principles of surgical oncology for mesenchymal tumors, including complete surgical excision in the case of presumably benign tumors. In this case, we performed a complete tumor resection. The tumor type was confirmed as a solitary calcifying fibrous tumor, so neither radiation therapy nor chemotherapy was required. The postoperative course of the patient was uneventful.

\section{Conclusion}

Diaphragmatic tumors of mesenchymal origin are an orphan disease characterized by a predominantly benign type of growth. Their often non-specific clinical manifestations lead to delayed diagnosis. Key preoperative assessment must include CT and MRI visualization. Surgical excision is the gold standard for definitive treatment. With complete removal of the tumor, the prognosis is quite favorable. (8)

\section{Additional information}

\section{Informed consent statement}

The patient has voluntarily signed her informed consent to the publication of personal medical information in an anonymized form in the Almanac of Clinical Medicine journal.

\section{Conflict of interests}

The authors declare no conflict of interests.

\section{Authors' contributions}

All the authors have made an equal contribution to the manuscript. All the authors have read and approved the final version of the manuscript before submission, agreed to be accountable for all aspects of the work in ensuring that questions related to the accuracy or integrity of any part of the work are appropriately investigated and resolved.

Acknowledgements

We would like to thank the patient for giving us her written consent for publishing her medical information.

\section{References}

1. Gierada DS, Slone RM, Fleishman MJ. Imaging evaluation of the diaphragm. Chest Surg Clin N Am. 1998;8(2):237-280.

2. Baldes N, Schirren J. Primary and Secondary Tumors of the Diaphragm. Thorac Cardiovasc Surg. 2016;64(8):641-646. doi: 10.1055/s0036-1582256.

3. Weksler B, Ginsberg RJ. Tumors of the diaphragm. Chest Surg Clin N Am. 1998;8(2):441447.

4. England DM, Hochholzer L, McCarthy MJ. Localized benign and malignant fibrous tumors of the pleura. A clinicopathologic review of 223 cases. Am J Surg Pathol. 1989;13(8):640658. doi: 10.1097/00000478-198908000-00003.

5. Brunnemann RB, Ro JY, Ordonez NG, Mooney J, El-Naggar AK, Ayala AG. Extrapleural solitary fibrous tumor: a clinicopathologic study of 24 cases. Mod Pathol. 1999;12(11):1034-1042.

6. Grancher M. Tumeur végétante du centre phrénique du diaphragme. Bull Soc Anat Paris. 1868;43:385.
7. Cheng Y, Zhang C, Gao Y, Dong S. [Rare solitary fibrous tumor of diaphragmatic pleura: a case report]. Zhongguo Fei Ai Za Zhi. 2012;15(1): 59-61. Chinese. doi: 10.3779/j.issn.10093419.2012.01.13.

8. Kita Y. [Pleural solitary fibrous tumor from diaphragm, being suspected of liver invasion; report of a case]. Kyobu Geka. 2012;65(4):338340. Japanese.

9. Ge W, Yu DC, Jiang CP, Ding YT. Giant solitary fibrous tumor of the diaphragm: a case report and review of literature. Int J Clin Exp Pathol. 2014;7(12):9044-9049.

10. Liu D, Wang Y, Zheng Y, Zhang HL, Wang ZH. Massive malignant solitary fibrous tumor of the diaphragm: A case report. Medicine (Baltimore). 2020;99(5):e18992. doi: 10.1097/ MD.0000000000018992.

11. Liu CC, Wang HW, Li FY, Hsu PK, Huang MH, Hsu WH, Hsu HS, Wang LS. Solitary fibrous tumors of the pleura: clinicopathological characteristics, immunohistochemical profiles, and surgical outcomes with long-term follow-up. Thorac Cardiovasc Surg. 2008;56(5):291-297. doi: 10.1055/s-2007-965767.

12. Lahon B, Mercier O, Fadel E, Ghigna MR, Petkova B, Mussot S, Fabre D, Le Chevalier T, Dartevelle P. Solitary fibrous tumor of the pleura: outcomes of 157 complete resections in a single center. Ann Thorac Surg. 2012;94(2):394-400. doi: 10.1016/j.athoracsur.2012.04.028.

13. Ota H, Kawai H, Yagi N, Ogawa J. Successful diagnosis of diaphragmatic solitary fibrous tumor of the pleura by preoperative ultrasonography. Gen Thorac Cardiovasc Surg. 2010;58(9): 485-487. doi: 10.1007/s11748-009-0551-9.

14. Enon S, Kilic D, Yuksel C, Kayi Cangir A, Percinel S, Sak SD, Gungor A, Kavukcu S, Okten I. Benign localized fibrous tumor of the pleura: report of 25 new cases. Thorac Cardiovasc Surg. 2012;60:468-473. doi: 10.1055/s-00311295519. 


\section{Опухоль диафрагмы, симулирующая новообразование желудка: клиническое наблюдение}

\author{
Бурко П.А. • Федорова М.Г. ${ }^{2}$ Ильясов Р.Р. ${ }^{3}$ • Можжухина И.Н. ${ }^{4}$
}

Подавляющее большинство пациентов с опухолями, исходящими из диафрагмы, не имеют специфических клинических симптомов, что определяет необходимость использования современных методов визуализации, таких как компьютерная (КТ) или магнитно-резонансная томография (МРТ). Это особенно актуально в случаях, когда патологическое образование увеличивается настолько, что оказывает «масс-эффект» на смежные органы. В некоторых ситуациях клинические симптомы злокачественного новообразования возникают из-за местной инвазии в соседние ткани или при формировании отдаленных метастазов.

Мы представляем редкое клиническое наблюдение мезенхимальной опухоли диафрагмы у 34-летней пациентки. После анализа клинического статуса и визуализации брюшной полости методами КТ и МРТ был установлен предварительный диагноз «Новообразование неопределенного или неизвестного характера желудка» (D37.1). Вместе с тем было сделано предположение об экзогастральном расположении объемного образования в соответствии с данными МРТ. По результатам обследования коллегиально было принято решение о проведении хирургического лечения посредством лапароскопическойрезекции.Интраоперационно обнаружена опухоль, исходящая из левого купола диафрагмы. Соответственно, никаких изменений со стороны желудка не обнаружено. Послеоперационный период был без осложнений. Патологоанатомическое исследование, проведенное после резекции опухоли, выявило одиночную кальцинирующую фиброзную опухоль диафрагмы.

Приведенный клинический пример показывает, что образование, исходящее из диафрагмы, может имитировать образование, происходящее из дна желудка. Это следует иметь в виду во избежание установления ошибочного диагноза и неверной тактики лечения.

Ключевые слова: солитарная фиброзная опухоль, мезенхимальная опухоль, диафрагма, желудок, компьютерная томография, магнитно-резонансная томография

Для цитирования: Бурко ПА, Федорова МГ, Ильясов РР, Можжухина ИН. Опухоль диафрагмы, симулирующая новообразование желудка: клиническое наблюдение. Альманах клинической медицины. 2021;49(7):503-507. doi: 10.18786/2072-05052021-49-063.

Поступила 20.09.2021; доработана 14.12.2021; принята к публикации 17.12.2021; опубликована онлайн 20.12.2021

\section{Согласие пациента}

Пациентка добровольно подписала информированное согласие на публикацию персональной медицинской информации в обезличенной форме в журнале «Альманах клинической медицины».

\section{Финансирование}

Работа выполнена по инициативе авторов без привлечения финансирования.

\section{Конфликт интересов}

Авторы декларируют отсутствие явных и потенциальных конфликтов интересов, связанных с публикацией настоящей статьи.

\section{Участие авторов}

Все авторы внесли равный вклад в написание статьи. Все авторы прочли и одобрили финальную версию статьи перед публикацией, согласны нести ответственность за все аспекты работы и гарантируют, что ими надлежащим образом были рассмотрены и решены вопросы, связанные с точностью и добросовестностью всех частей работы.

Благодарности

Авторский коллектив тепло благодарит пациентку за разрешение опубликовать ее медицинские данные в научных целях.
Бурко Павел Александрович - врачрентгенолог отделения лучевой диагностики'; ORCID: https://orcid.org/0000-0002-1344-9654 $\triangle 121099$, г. Москва, ул. Новый Арбат, 32, Российская Федерация. Тел.: +7 (977) 6241462 E-mail: pavelburko@gmail.com

Федорова Мария Геннадьевна - канд. мед. наук, доцент, заведующая кафедрой морфологии Медицинского института²; ORCID: https://orcid. org/0000-0003-4177-8460.

E-mail: fedorovamerry@gmail.com

Ильясов Руслан Рамильевич - врач-хирург отделения хирургии ${ }^{3}$; ORCID: https://orcid. org/0000-0003-0873-1804. E-mail: diamonddoctor@mail.ru

Можжухина Ирина Николаевна - канд. мед. наук, доцент, заведующая кафедрой рентгенологии ; ORCID: https://orcid.org/00000002-0777-1604.

E-mail: mogira1972@yandex.ru
'ФГБУ «Национальный медицинский исследовательский центр реабилитации и курортологии» Минздрава России; 121099, г. Москва, ул. Новый Арбат, 32, Российская Федерация

2 ФГБОУ ВО «Пензенский государственный университет»; 440026, г. Пенза, ул. Красная, 40, Российская Федерация

${ }^{3} \mathrm{OOO}$ «Клиника диагностики и лечения на Измайлова»; 440023, г. Пенза, ул. Измайлова, 71, Российская Федерация

${ }^{4}$ Пензенский институт усовершенствования врачей - филиал ФГБОУ ДПО «Российская медицинская академия непрерывного профессионального образования» Минздрава России; 440060, г. Пенза, ул. Стасова, 8А, Российская Федерация 